\title{
Superior orbital fissure syndrome after facial trauma
}

\author{
Síndrome da fissura orbitária superior após trauma de face \\ Síndrome de fisura orbital después de trauma facial \\ Ellen Cristina GAETTI JARDIM ${ }^{\mathbf{1}}$ \\ Leonardo Perez FAVERANI ${ }^{2}$ \\ Danilo Chizzolini MASOCATTO ${ }^{3}$ \\ Murilo Moura OLIVEIRA ${ }^{4}$ \\ Shajadi Carlos Pardo KABA ${ }^{5}$ \\ Elerson Gaetti JARDIM JUNIOR ${ }^{6}$ \\ Julio Cesar Leite da SILVA ${ }^{7}$ \\ Elio Hitoshi SHINOHARA ${ }^{8}$
}

${ }^{I}$ PhD. Department of Oral and Maxillofacial Surgery, School of Dentistry, Federal University of Mato Grosso do Sul (UFMS), Campo Grande, MS, Brazil

${ }^{2}$ PhD. Department of Oral and Maxillofacial Surgery, School of Dentistry,

São Paulo State University (UNESP), Araçatuba, SP, Brazil

${ }^{3}$ Oral and Maxillofacial Surgeon. Master Student

Federal University of Mato Grosso do Sul (UFMS), Campo Grande, MS, Brazil

${ }^{4}$ Oral and Maxillofacial Surgeon. Master Student

Federal University of Mato Grosso do Sul (UFMS), Campo Grande, MS, Brazil ${ }^{5}$ Oral and Maxillofacial Surgeon

${ }^{6}$ PhD. Department of Pathology and Clinical Propedeutics, School of Dentistry, São Paulo State University (UNESP), Araçatuba, SP, Brazil

${ }^{7}$ PhD. Department of Oral and Maxillofacial Surgery, School of Dentistry,

Federal University of Mato Grosso do Sul (UFMS), Campo Grande, MS, Brazil

${ }^{8}$ Department of Oral and Maxillofacial Surgery, School of Dentistry,

São Paulo State University (UNESP), Araçatuba, SP, Brazil

\begin{abstract}
The superior orbital fissure is a crack that communicates with the middle cranial fossa and is located between the greater and lesser wings of the sphenoid in the posterior region of the orbit. It presents a close relationship with several important structures such as the optic foramen and II, III, IV, V and VI cranial nerve and the sphenoid and ethmoid sinuses. Zygomatic-orbital fracture may trauma in the posterior region of the orbit and may result in the Superior Orbital Fissure Syndrome (SOFS) or Apex Orbital Syndrome (AOS). The superior orbital fissure syndrome results from compression structures that pass this region, resulting in paralysis of the cranial nerves III, IV and VI. Clinically, the patient has ptosis, mydriasis and ophthalmoplegia, it is very important that the diagnosis is made before the surgical manipulation of reduction and fixation of zygomatic fracture. Case report: A male patient, 37, hit and run victim was survived by Trauma Surgery Team. Diagnosed with head trauma and diffuse axonal injury, it was transferred to the Intensive Care Unit (ICU) where he stayed for three weeks. It was conducted by the Oral and Maxillofacial Surgery and was diagnosed zygomaticomaxillary fracture type Le Fort III and mandibular fracture associated with SOFS. The surgical treatment of mandibular and zygomaticomaxillary fractures was conducted. The ptosis devolved and postoperative 6 months was noted complete remission of the syndrome signals.

Descriptors: Craving; Optical Nerve; Syndrome; Cranial Nerve.
\end{abstract}

\section{Resumo}

A fissura orbitária superior é uma fenda que se comunica com a fossa craniana média e localiza-se entre as asas maior e menor do esfenoide na região posterior da órbita. Apresenta íntima relação com diversas estruturas nobres, como o forame óptico e os II, III, IV, V e VI pares cranianos e os seios esfenoidal e etmoidal. Fratura zigomático-orbitária pode desencadear trauma na região posterior da órbita, podendo resultar na Síndrome da Fissura Orbitária Superior (SFOS) ou na Síndrome do Ápice Orbitário (SAO). A síndrome da fissura orbitária superior é resultante da compressão de estruturas que passam nessa região, resultando na paralisia dos pares cranianos III, IV e VI. Clinicamente o paciente apresenta ptose palpebral, midríase e oftalmoplegia, sendo muito importante que o diagnóstico seja feito anteriormente a manipulação cirúrgica de redução e fixação da fratura de zigoma. Relato de caso: Paciente do gênero masculino, 37 anos, vítima de atropelamento, foi socorrido por Equipe de Cirurgia do Trauma. Com diagnóstico de traumatismo craniano e lesão axonal difusa, o mesmo foi transferido para Unidade de Terapia Intensiva (UTI) aonde permaneceu por 3 semanas. Foi reavaliado pela Cirurgia e Traumatologia Bucomaxilofacial e diagnosticou-se fratura zigomático-maxilar do Tipo Le fort III e fratura mandibular associado a SFOS. Realizou-se tratamento cirúrgico das fraturas mandibular e zigomático-maxilares. A ptose palpebral involuiu e no pós-operatório de 6 meses notou-se completa remissão dos sinais da referida síndrome.

Descritores: Fissura; Nervo Óptico; Síndrome; Nervos Cranianos.

\section{Resumen}

La fisura orbital superior es una ranura que se comunica con la fosa craneal media y se encuentra entre el mayor y menor ala del esfenoides en la región posterior de la órbita. Características estrecha relación con diversas estructuras importantes, tales como el agujero óptico y II, III, IV, V y VI nervios craneales y esfenoides, seno etmoidal. trauma fractura malar-orbital puede desencadenar la región posterior de la órbita, puede dar lugar a síndrome de fisura orbital superior (SFOS) o el síndrome del vértice de la órbita (LAS). Los orbitales resultados síndrome de fisura superiores de estructuras de compresión que pasan esta región, dando lugar a parálisis de los nervios craneales III, IV y VI. Clínicamente, el paciente tiene ptosis, midriasis y oftalmoplejía, es muy importante que el diagnóstico se realiza antes de la reducción manipulación cigoma quirúrgica y fijación de fracturas. Caso clínico: Paciente de sexo masculino, de 37 años, golpeó y ejecutar víctima fue sobrevivido por Trauma equipo de cirugía. Diagnosticado con traumatismo craneal y lesión axonal difusa, que fue trasladado a la Unidad de Cuidados Intensivos (UCI), donde permaneció durante tres semanas. Se reevaluado por cirugía oral y maxilofacial y fue diagnosticado zygomaticomaxillary tipo de fractura Le Fort III y fractura mandibular asociado con SFOS. tratamiento quirúrgico realizado de fracturas mandibulares y maxilares-cigomático. La ptosis recayó y postoperatorias 6 meses se observó una remisión completa de las señales de síndrome.

Descriptores: Ansia; Nervio Óptico; Síndrome; Nervios Craneales. 


\section{INTRODUCTION}

The first care conferred by health professionals to polytrauma exerts decisive character regarding the outcome of the case. The attendant is given sequentially, so that many steps are performed concurrently. Therefore, attention is directed to serious injuries and the search for immediate treatment and, often blunders result in serious or even sequelae death ${ }^{1}$.

In this context, the superior orbital fissure (SOF) is a narrow slit which connects the cavernous sinus cranial fossa. It is a functionally important structure located between the larger wings and smaller sphenoid bone in the body, and have the nerves oculomotor, trochlear, nasociliary, and abducens, the three branches of the ophthalmic nerve, the orbital branch of the middle meningeal artery, the applicant branch meningeal of lacrimal artery, ophthalmic veins, and sympathetic fibers inside $^{2,3}$.

Damage to this region can be called Apex Orbital Syndrome (AOS) or Superior Orbital Fissure Syndrome (SOFS) this being caused by compression or even rupture of the said fissure content. As features to ophthalmoplegia, ptosis, pain, pupil dilation addition to fixing the same, exophthalmos, lacrimal nerve hypofunction, and anesthesia of frontal region of the nose and the cornea may be present $^{2}$.

Common causes include cancer, inflammation or trauma often associated with craniofacial fractures simultaneous ${ }^{4}$. Thus, the purpose of this report is to present the case of a patient, hit and run victim with multiple facial fractures resulting in Superior Orbital Fissure Syndrome.

\section{CASE REPORT}

Patient 37 year old male, was presented to the Hospital Service, victim of trampling being helped initially by the Surgery of Trauma Team. Diagnosed with head trauma and diffuse axonal injury it was transferred to ICU where he remained for three weeks.

The patient was evaluated by the surgery team and Maxillofacial and examination was diagnosed zygomaticomaxillary type fractures Le Fort III and mandibular fracture associated with SOFS. He diagnosed to SOFS by the sum of the signs and symptoms associated with the image data with the presence of ophthalmoplegia, dilated pupil, positive response to light and significant ptosis without damage to the overlying soft tissue presenting palpable bony step in the orbital rim. The other fractures were confirmed by routine radiographs (Figures $1 \mathrm{a}$ and $1 \mathrm{~b})$.

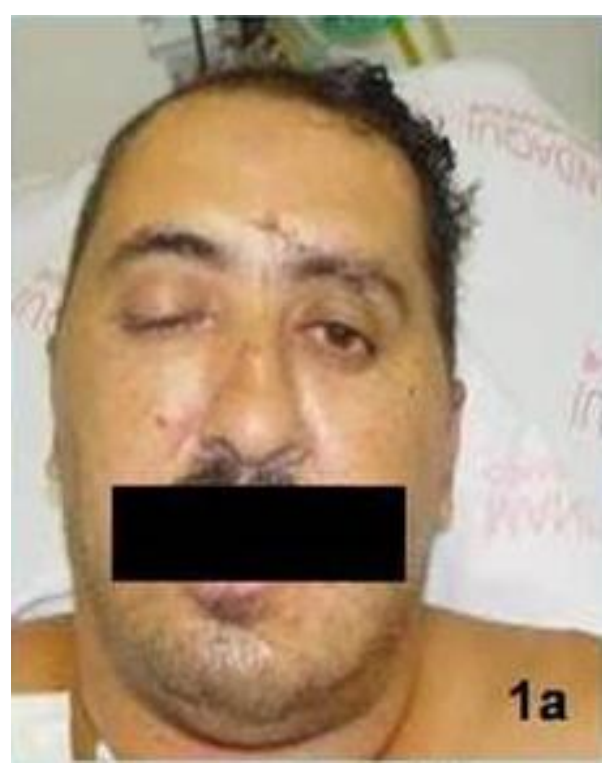

Figure 1a: Ophthalmoplegia and dilated pupil.

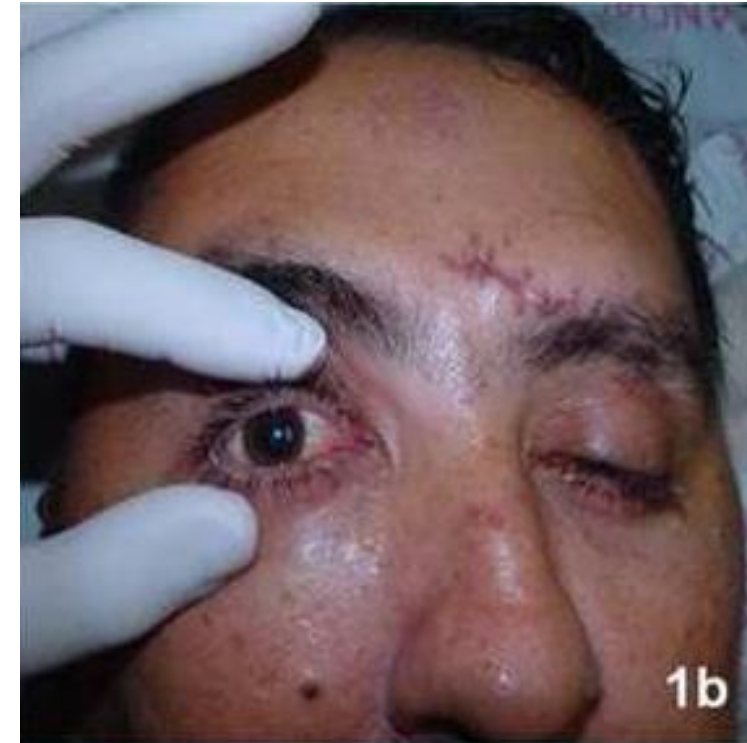

Figure 1b: Ophthalmoplegia and dilated pupil.

Computed tomography (CT) showed a comminuted fracture of the greater wing of the sphenoid formed by the side wall of the superior orbital fissure beyond the nasal bones fracture, minimally displaced and no evidence of any other bone injury (Figure 1c).

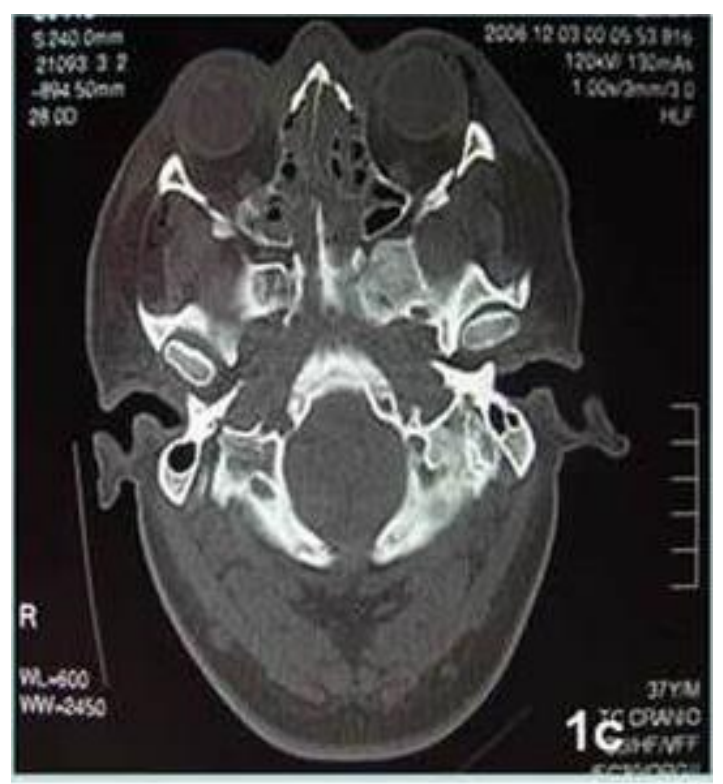

Figure 1c: Zygomaticomaxillary type fractures Le Fort III and mandibular fracture associated with SOFS.

In view of this case, it was proposed surgery for reduction and fixation of mandibular and zygomaticmaxillary fractures under general anesthesia. The surgical approaches used for fractures were the labial intraoral access for mandible and maxilla mimicking this access to Le Fort I got a plate in $\mathrm{L}$ on each pillar of bilateral jaw $1.5 \mathrm{~mm}$ and $2.4 \mathrm{~mm}$ system system reconstruction plate in the mandible (Figures $2 \mathrm{a}$ to $2 \mathrm{~d}$ ).

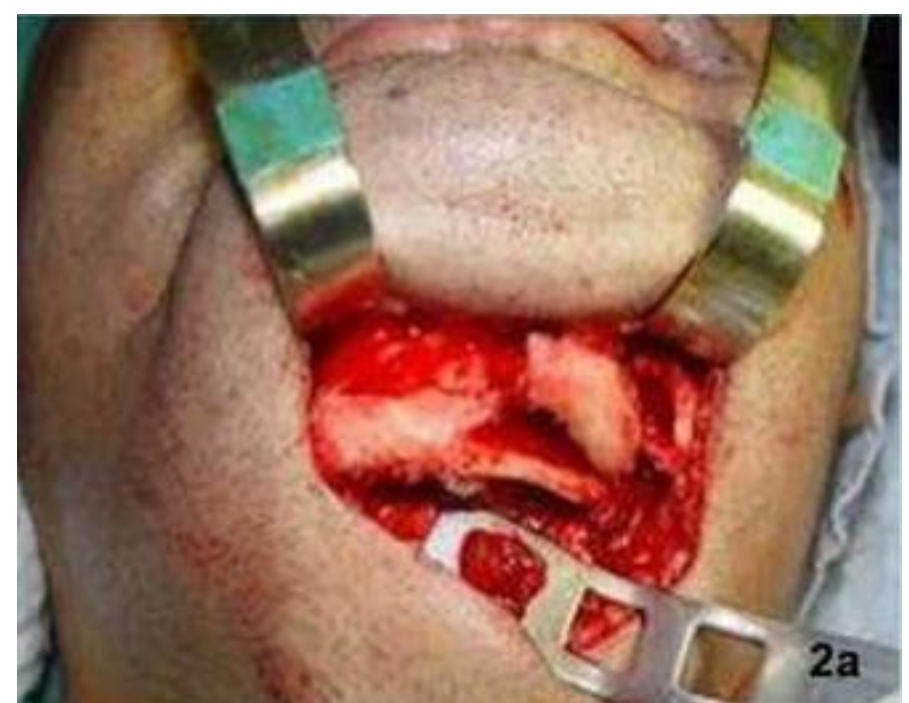

Figure 2a: Surgical approaches and $1.5 \mathrm{~mm}$ and $2.4 \mathrm{~mm}$ system reconstruction plate. 


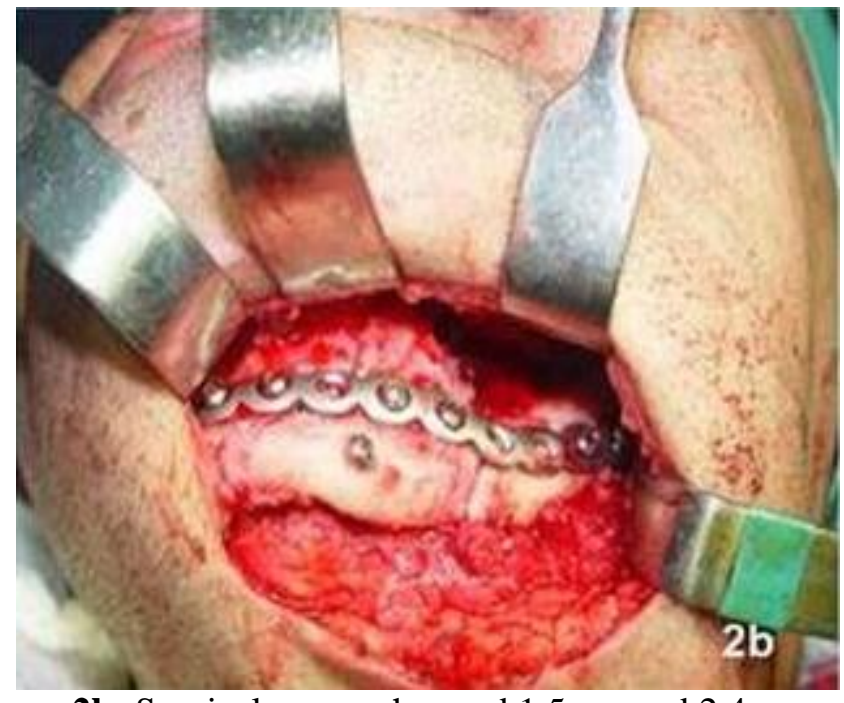

Figure 2b: Surgical approaches and $1.5 \mathrm{~mm}$ and $2.4 \mathrm{~mm}$ system reconstruction plate.

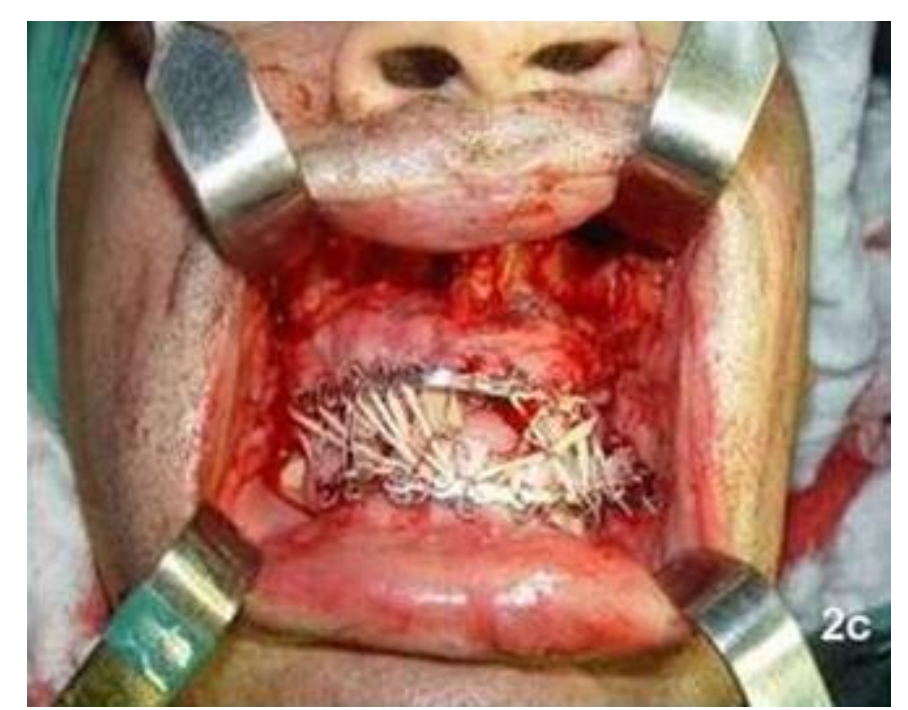

Figure 2c: Surgical approaches and $1.5 \mathrm{~mm}$ and $2.4 \mathrm{~mm}$ system reconstruction plate.

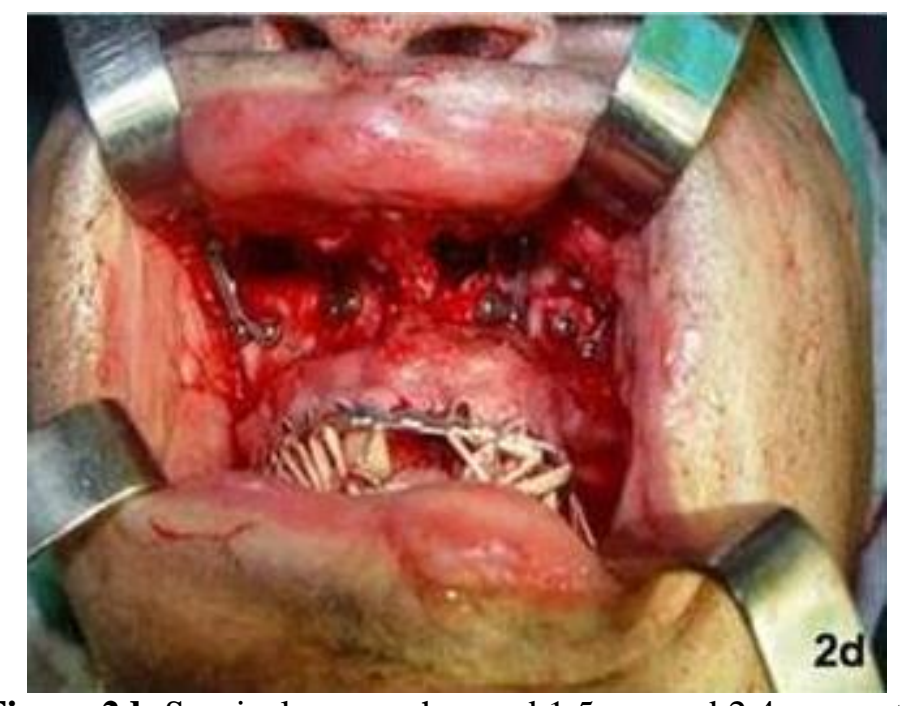

Figure 2d: Surgical approaches and $1.5 \mathrm{~mm}$ and $2.4 \mathrm{~mm}$ system reconstruction plate.

The orbital fracture was treated conservatively. At 4 weeks post-operative revision (Figures $3 \mathrm{a}$ to $3 \mathrm{c}$ ) showed improvement in acuity and ocular motility.

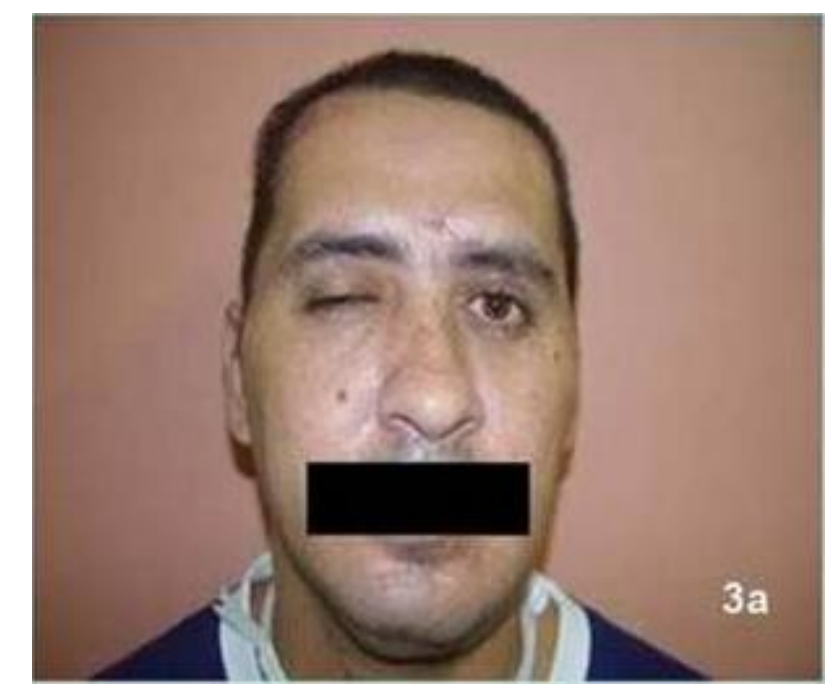

Figure 3a: Four weeks post-operative revision. Presence of signs associated with syndrome.

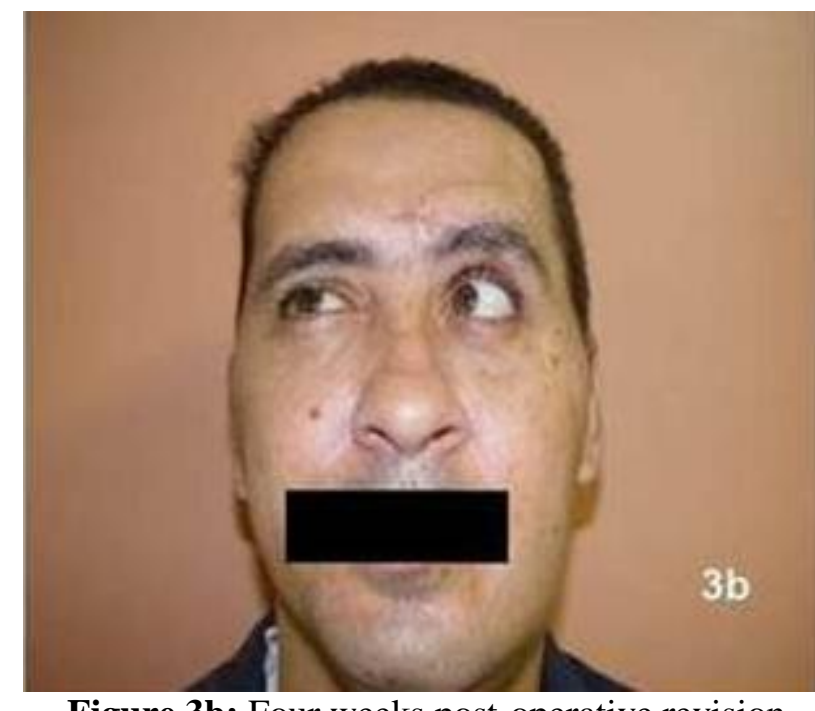

Figure 3b: Four weeks post-operative revision. Presence of signs associated with syndrome.

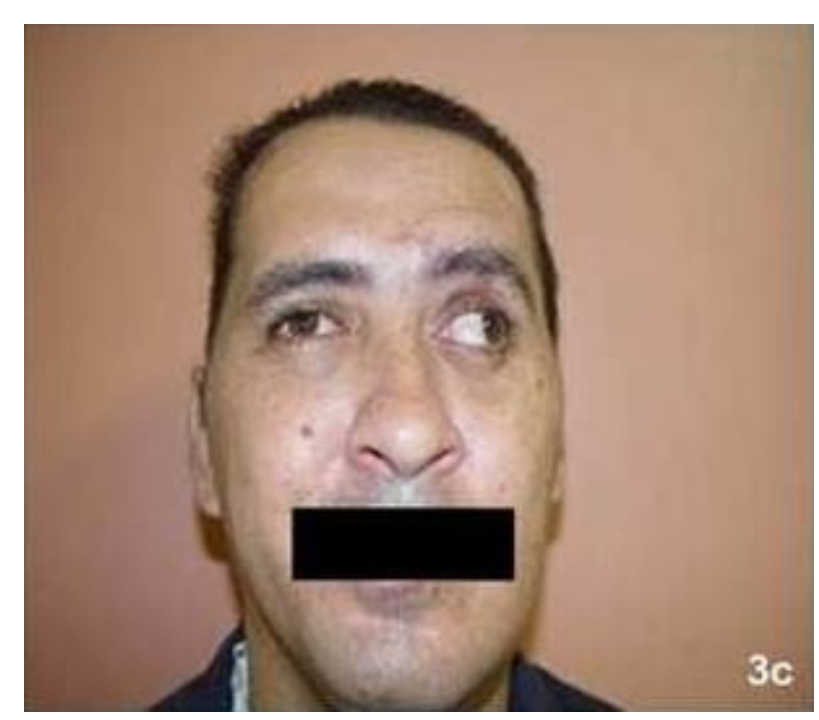

Figure 3c: Four weeks post-operative revision. Presence of signs associated with syndrome.

The ptosis devolved and postoperative 6 months was noted complete remission of signs related syndrome (Figures $4 \mathrm{a}$ to $4 \mathrm{~d}$ ).

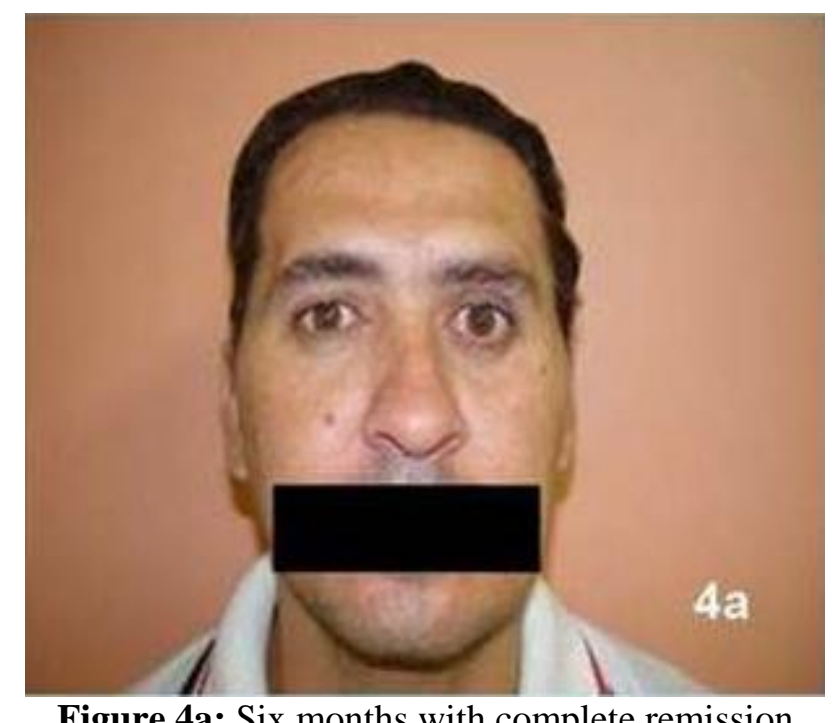

Figure 4a: Six months with complete remission of signs related syndrome.

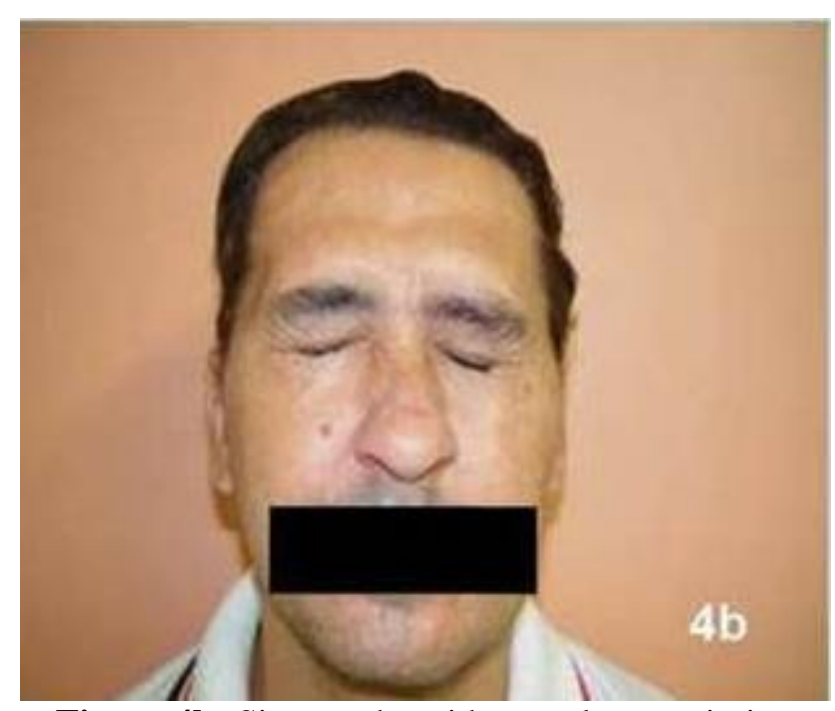

Figure 4b: Six months with complete remission of signs related syndrome. 


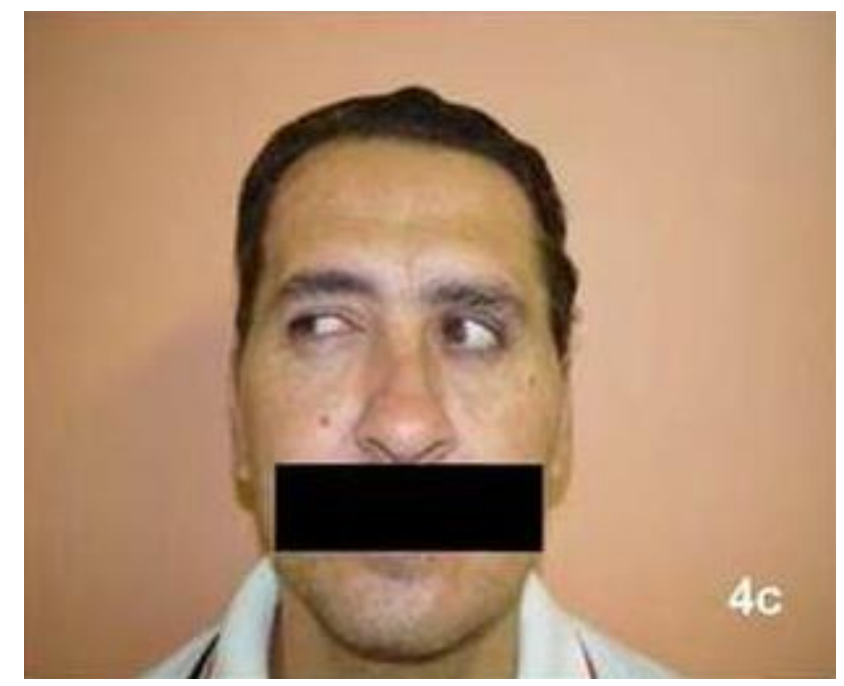

Figure 4c: Six months with complete remission of signs related syndrome.

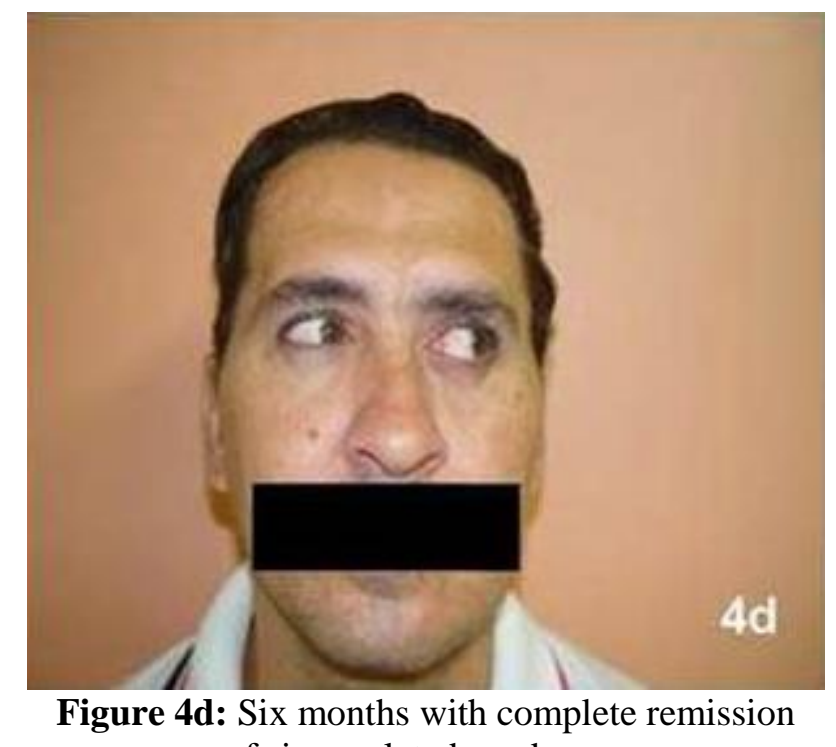
of signs related syndrome.

\section{DISCUSSION}

Currently, facial trauma is a public health concern, not only by a high prevalence to devastating aggression especially the emotional consequences beyond the economic impact that causes in a health system can affect not only the soft tissue and bone but also its structures adjacent to the brain, eyes and nervous structures and teeth ${ }^{5}$.

The complexity of the orbital apex is related to the confluence of critical neurovascular structures in the skull transition to orbit and face. In this sense SOFS reflects neurovascular structures injuries crossing the superior orbital fissure causing ptosis and ophthalmoplegia (cranial nerves III, IV, VI), proptosis (superior ophthalmic vein), and anesthesia of the upper eyelid and forehead (cranial nerve V1) and occurs in complete or partial form fit to the etiology trauma, infection, tumors or haemorrhages ${ }^{4,6,7}$. This fact corroborates the case already presented that the patient was the victim of car accident by trampling resulting in multiple fractures of face associated with SOFS which increases the complexity of the case difficult treatment plan by a professional with little experience.

Comprehensive radiological investigation should detail the bone and neuromuscular aiding in the treatment plan acting as a surgical guide. Although magnetic resonance set with greater fidelity the orbital apex, Computed Tomography (CT) should be used in the presence of damage to the orbital framework ${ }^{8}$. CT is important for diagnosis, particularly as regards the extent of the trauma, but without a clinical examination accurate it does not have much value. The patient should be examined properly both regarding acuity and ocular motility as compared to bone contours, extrinsic muscles and overlying soft tissues as seen in our patient.
Rowe \& Williams ${ }^{9}$ they indicate that in patients with SOFS surgical procedures for reduction and fixation of zygomatic complex fractures should be postponed for a period of 10 to 14 days, in an attempt not to cause further damage to the nerves located in the orbital apex region. Already Bun et al. $^{7}$ indicates the treatment of facial fractures as soon as the general conditions allow patient. Corroborating the literature treating our patient materialized at the time of clinical improvement and ICU release, fact associated with corticosteroid therapy associated with antibiotic prophylaxis alleviate swelling that can compress the nerves and muscles overlying.

The etiology of SOFS is wide and determines the treatment plan as well as the prognosis of the case. The prognosis becomes poor when there is compression of the fissure components in large bone involvement situations, the opposite is observed because the injury usually is located at the level of the periosteum. In our case, it was possible to justify the diagnosis of the superior orbital fissure syndrome by indirect trauma with displacement spheno-ethmoid mass presenting clinically ptosis and pupillary dilation beyond ophthalmoplegia.

Regarding the other fracture presented by the patient, the same were treated as guides to literature pricing zygomaticomaxillary complex at 4 points the zygomaticomaxillary pillar bilaterally and canines pillars bilaterally. In the mandible, allows the use of a robust plate over the fracture $2.4 \mathrm{~mm}$ as used in the system that gave stability to the case. In this report, the comminution of the jaw associated with major occlusal unevenness due to the complex fracture of the jaw increased the degree of complexity of the case. The proposed treatment plan was favorable generating stability accompanied case of satisfactory alignment of the fractured bone stumps.

The resulting pressure gradient of one in orbit trauma as a result of swelling or bruising may be associated with a number of signs and symptoms as those presented by the patient, as well as headaches, eye discomfort, or hear a synchronized noise with pulsing of blood vessels. These symptoms may be present directly after the trauma or may develop several days, weeks or months later ${ }^{9,10}$ this fact confirms the preservation of the case and no surgical intervention in orbit showing complete remission of symptoms.

\section{CONCLUSION}

The SOFS is a rare complication whose diagnosis is eminently clinical and the fundamental careful physical examination for the correct diagnosis and appropriate treatment plan. Clinical follow-up in the long term is key.

\section{REFERENCES}

1. Yeh S, Foroozan R. Orbital apex syndrome. Curr Opin Ophthalmol. 2004; 15(6):490-8.

2. Foroozan R, Bhatti MT, Rhoton AL. Transsphenoidal diplopia. Surv Ophthalmol. 2004; 49(3):349-58.

3. Kline LB. The Tolosa-Hunt syndrome. Surv Ophthalmol. 1982;27(2):79-95

4. McAvoy CE, Lacey B, Page AB. Traumatic superior orbital fissure syndrome. Eye (Lond). 2004; 18(8):8445.

5. Ykeda RB, Ballin CR, Moraes RS, Ykeda RB, Miksza AF. Epidemiological profile of 277 patients with facial fractures treated at the emergency room at the Ent 
Department of Hospital do Trabalhador in Curitiba/PR, in 2010. Int Arch Otorhinolaryngol. 2012; 16(4):437-44.

6. Gabikian P, Chowdhary AM, Kott B, Lazar DA, Britz GW. Isolated Superior Orbital Fissure Syndrome Resulting From Gunshot Wound to the Head. Curr Probl Diagn Radiol. 2012; 41(4):112-3.

7. Bun RJ, Vissink A, Bos RR. Traumatic superior orbital fissure syndrome: Report of two cases. J Oral Maxillofac Surg. 1996;54(6):758-61.

8. Taylor KH, Mizen KD, Spencer N. Isolated fracture of the superior orbital fissure $\mathrm{Br} \mathrm{J}$ Oral Maxillofac Surg. 2010; 48(3):178-9.

9. Rowe NL, Williams JL (eds). Maxillofacial injuries. Edinburgh: Churchill Livingstone; 1985.

10. Paza AO, Farah GJ, Passeri LA. Traumatic carotid cavernous fistula associated with a mandibular fracture. Int J Oral Maxillofac Surg. 2008;37(1):86-9.

\section{CONFLICTS OF INTERESTS}

The authors declare no conflicts of interests.

\section{CORRESPONDING AUTHOR}

Ellen Cristina Gaetti Jardim

ellengaetti@gmail.com

Received 11/04/2017

Accepted 06/06/2017 